\title{
IN VITRO SELECTION AND CHARACTERIZATION OF SALVIA OFFICINALIS SALT-TOLERANT CLONES
}

\author{
M.A.H. Mohamed *, M.K. Aly *, E.T. Ahmed * and Sozan A. Abd El-Latif ** \\ * Dept. of Horticulture, Fac. of Agric., Minia Univ., Egypt \\ ** Dept. of Horticulture, Fac. of Agric., South Valley Univ., Egypt
}

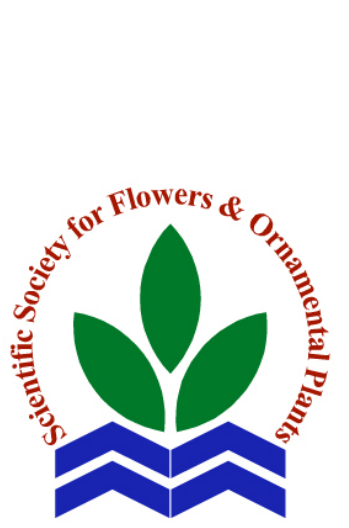

Scientific J. Flowers \& Ornamental Plants, 8(1):123-134 (2021).

Received:

$18 / 1 / 2021$

Accepted:

20/2/2021

Corresponding author: M.A.H. Mohamed mmahmohamed@gmail.com

ABSTRACT: Salvia officinalis L. is a widest-spread attractive plant in different pharmacopoeias throughout the world. Shoot clumps were regenerated from leaf explants on MS medium enriched with $1 \mathrm{mg} / \mathrm{l}$ IAA $+1.5 \mathrm{mg} / \mathrm{l} \mathrm{TDZ}$. A 12-week old shoot clumps were subcultured on the same medium supplemented with $100 \mathrm{mM}$ of $\mathrm{NaCl}$. After 12 weeks 4 shoots were recovered from 60 cultured shoot clumps. These shoots were elongated and individually cloned on MS medium enriched with $1 \mathrm{mg} / 1 \mathrm{IAA}$. Single nodes of the recovered clone, as well as, the control plants were cultured using a single node explants on MS medium enriched with $1 \mathrm{mg} / \mathrm{l} \mathrm{IAA}$ and 0 or $100 \mathrm{mM} \mathrm{NaCl}$. After a month of growth on this medium statistical analysis showed significant difference among the selected clones and the control plants on the base of the ability to develop new growth, plant height, shoot and root fresh and dry weights, as well as, chlorophyll content. Moreover, there were significant differences among the selected colons on proline and total soluble protein content. Also, some regenerated clone showed higher activity of the free radical scavenging enzymes; catalase, peroxidase, and ascorbate peroxidase under salt stress. Therefore, somaclonal variation was used to select a drought tolerant $S$. officinals clone. Moreover, some physiological mechanisms that are crucial for salt stress tolerance were underlined.

Key words: abiotic stress, low-molecular-weight osmolytes, sage, scavenging enzymes, somaclonal variations.

\section{INTRODUCTION}

Salvia officinalis L. (sage or salvia) which belongs to the Labiatae family is a widest-spread attractive plant. It features clearly in different pharmacopoeias throughout the world. Salvia plants have been used in numerous ways, e.g. essential oils, the leaves, the flowers, the seed oil, and the roots (Dweck, 2000). The traditional use of this herb in the domestic medicine is endless; as a carminative, bactericidal, spasmolytic, mouthwash against its inflammation, a wound-healing agent, in skin and hair treatment; and against rheumatism and sexual debility in treating mental and nervous conditions as well as an insecticidal (Dweck, 2000 and Baricevic and Bartol, 2000).

Salinity and drought are expected to cause thoughtful salinization of more than half of world land by 2050. The growth and productivity of numerous crops is badly affected by these stresses causing enormous economic losses in affected areas (Rao and Sandhya, 2019). About 20\% of world irrigated land is significantly affected by salinity, decreasing crop yields. Plants are affected by salt stress in two chief ways: osmotic stress and ionic toxicity. These stresses affect all major plant processes, including photosynthesis, cellular metabolism, and plant nutrition (Gupta and Huang, 2014). 


\section{M.A.H. Mohamed et al.}

Low-molecular-weight osmolytes, comprising proline, as well as biosynthesis of free radical scavenging enzymes, such as catalase, peroxidase, and ascorbate peroxidase play important roles in sustaining cellular functions under abiotic stress (Brenes et. al., 2020 and de Castro et al., 2020). The in vitro adjustment of proline accumulation was extensively estimated in sodium-chloride- shock (Alhasnawi, 2019) moreover, this review article defined a tissue culture technique for the assessment and enhancement of salt tolerance in many plants.

Keunen et al. (2013) emphasized the role of total soluble sugars (TSS) on salt tolerance due to promoting osmotic adjustment. They confirmed the extending concept of antioxidants functioning during abiotic stress, with special focus on the key role of sugars as true ROS scavengers. During the onset and development of abiotic stress, all the primary processes such as photosynthesis, protein synthesis and lipid metabolisms are affected. A higher content of total soluble proteins (TSP) have been observed in abiotic tolerant cultivars of many plant species however, on other species TSP increase at low salinity and decreases at high salinity stress (Parvaiz and Satyawati, 2008).

Effective strategy for the in vitro selection of desire traits is a vital step in plant breeding programs. There are some considerations to select plant cells and regenerated colons for a new trait using somaclonal variations. The most frequently used approach for selection of stress tolerant genotypes involves culturing explants on medium supplemented with, mannitol, $\mathrm{NaCl}$, and PEG (Mohamed et al., 2000; Al-Amier and Craker, 2007; Ghaheri et al., 2017; Jolayemi et al., 2018; Singh et al., 2020 and De Castro et al., 2020).

Therefore, the aim of the current study was to induce somaclonal variations in regenerated $S$. officinalis plants in order to select $\mathrm{NaCl}$-tolerant clones using a rapid in vitro regeneration protocol (Mohamed et al., 2019). Furthermore, some physiological mechanisms that are crucial for drought stress tolerance were investigated.

\section{MATERIALS AND METHODS}

\section{Plant materials and culture conditions:}

Salvia officinalis single-node explants were collected from field-grown plants and cultured in vitro using a routine protocol previously described by Mohamed et al. (2019). Apical shoots from developing plantlets were excised and individually cultured on MS medium (Murashige and Skoog, 1962) fortified with $30 \mathrm{~g} / 1$ sucrose, and indole 3 -acetic acid (IAA) at $1.0 \mathrm{mg} / 1$ (shoot growth medium; SGM). Developing plantlets were used as a plant material for the next experiments.

For all culture media $\mathrm{pH}$ was adjusted to 5.8 and gelled with $8 \mathrm{~g} / 1$ agar then autoclaved for $20 \mathrm{~min}$ at $121{ }^{\circ} \mathrm{C}$ and 1.06 $\mathrm{kg} \mathrm{cm}^{-2}$. The vessels (jam jar; $250 \mathrm{ml}$ ) containing the cultures were incubated in a culture room at $23 \pm 1{ }^{\circ} \mathrm{C}$ and $16 \mathrm{~h}$ photoperiod provided by Phillips TLD $50 \mathrm{~W} /$ 84 HF fluorescent tubes giving a photon flux of approximately $40-50 \mu \mathrm{mol} \mathrm{m}{ }^{-2} \mathrm{~s}^{-1}$.

\section{Optimizing $\mathrm{NaCl}$ concentration for salt stress:}

A preliminary experiment was carried out to optimize the $\mathrm{NaCl}$ concentration which could be used as a selective agent. Single nodes were cultured on SGM enriched with $0,25,50,75,100,125,150$ $\mathrm{mM}$ of $\mathrm{NaCl}$. For each treatment there were 6 jars each with 5 explants. Explants were transferred onto a fresh medium every 4 weeks. After 8 weeks, the ability of explants to show new growth, rooting $\%$, and the fresh and dry (after drying at $70{ }^{\circ} \mathrm{C}$ ) weights of both shoots and roots were measured.

\section{Shoot regeneration on medium containing mannitol:}

Mohamed et al. (2019) previously stated that leaf explants of $S$. officinalis plants cultured on MS medium with $1.5 \mathrm{mg} / 1$ thidiazuron (TDZ) $+0.1 \mathrm{mg} / 1 \mathrm{IAA}$ and $3 \%$ sucrose (regeneration medium; RM) had the highest significant shoot number (7.2 
shoots/explant) after developing callus as compared with other investigated treatments. Therefore, this RM was used for in vitro selection of $\mathrm{NaCl}$-tolerant clones.

Leaf explants as well as, the regenerated shoot clumps from leaf explants which cultured on RM for 4 or 12 weeks were cultured on RM supplemented with $100 \mathrm{mM}$ $\mathrm{NaCl}$ for 12 weeks. The cultured explants were subcultured onto a fresh medium every 4 weeks. There were 30 explants for each treatment equally cultured on 6 jars.

\section{Shoot elongation:}

A number of 60 shoot clumps which developed from leaf explants on free- $\mathrm{NaCl}$ RM for 8 weeks before subculturing on the same medium but fortified with $100 \mathrm{mM}$ $\mathrm{NaCl}$ for 12 weeks were recovered. These recovered shoot clumps were cultured on SGM supplemented with $100 \mathrm{mM} \mathrm{NaCl}$. After 12 weeks 4 shoots were recovered and individually multiplicated as clones by a single node on free-NaCl SGM till having 30 plants from each clone.

\section{Evaluation the selected clones for $\mathrm{NaCl}$ stress:}

Plantlets of the 4 selected clones were divided into single nodes and equally cultured on SGM with 0 or $100 \mathrm{mM} \mathrm{NaCl}$. Explants were subcultured onto a fresh medium every 4 weeks. After 8 weeks shoot length, shoot and root fresh weight were assessed. Moreover, the following chemical and physiological parameters were measured.

\section{Chlorophyll content as SPAD unit:}

Total chlorophyll content was determined using a portable Minolta chlorophyll device SPAD-502 which has a $0.71 \mathrm{~cm}^{2}$ measurement area and based on absorbance measurements at 660 and $940 \mathrm{~nm}$ (Spectrum Technologies, Inc., Plainfield, IL, USA). Thirty separate measurements were made using the leaves from 30 plants in each treatment (Uddling et al., 2007).

\section{Proline, TSS and TSP determination:}

Fresh leaves form the same clone were mixed together then 3 randomized samples each of $0.1 \mathrm{~g}$ were used to assess the content of proline (Bates et al., 1973), TSS, (Jermyn, 1975), and TSP (Lowry et al., 1950).

\section{Estimation of some antioxidant enzymes activity:}

A Sample of $0.5 \mathrm{~g}$ of fresh leaves was frozen in liquid $\mathrm{N}$ and finely ground by pestle in a chilled motor as described by Mukherjee and Choudhuri (1983). The activity of CAT enzyme was estimated by the decrease of absorbance at $240 \mathrm{~nm}$ as a consequence of $\mathrm{H}_{2} \mathrm{O}_{2}$ consumption and was expressed according to Havir and Mellate (1987). The POX activity was assessed following Maehly and Chance (1954). The increase in absorbance due to formation of tetraguaiacol was observed at $470 \mathrm{~nm}$ (Klapheck et al., 1990). The APX activity was determined from the decrease in absorbance ascorbic at $290 \mathrm{~nm}$ as ascorbic acid oxidized (Asada, 1992).

\section{RESULTS AND DISCUSSION}

\section{Optimizing $\mathrm{NaCl}$ concentration for water stress:}

Table (1) shows that all estimated traits were significantly reduced by the addition of $\mathrm{NaCl}$ to the growth medium even at $25 \mathrm{mM}$. The ability of cultured nodes to show new growth was significantly reduced from $100 \%$ to $43 \%$ by increasing the concentration of $\mathrm{NaCl}$ from 0 to $100 \mathrm{mM}$. However, there was no difference among 25, 50 and $75 \mathrm{mM}$ but, at $125 \mathrm{mM}$ all explants died. Shoot length and fresh weights (FW) and dry weights (DW) were decreased $(\mathrm{p} \leq 0.5)$ due to $\mathrm{NaCl}$ treatments. Plant heights on $100 \mathrm{mM}$ $\mathrm{NaCl}$ were significantly reduced to $1.6 \mathrm{~cm}$ (compared with the control treatment; 8.2 $\mathrm{cm}$ ) (Fig. 1). Also, shoot dry weights under this concentration were reduced by more than 50\% compared with the control treatment $(1.80 \mathrm{~g} /$ plant $)$. Similar trend for the effect of $\mathrm{NaCl}$ on shoot DW were observed (Table, 1). The effects of $\mathrm{NaCl}$ on root $\mathrm{FW}$ 
M.A.H. Mohamed et al.

Table 1. Effect of $\mathrm{NaCl}$ on growth of Salvia officinalis single node explants after 8 weeks of culture on MS medium.

\begin{tabular}{cccccccc}
\hline \multirow{2}{*}{$\begin{array}{c}\mathbf{N a C l} \\
(\mathbf{m M})\end{array}$} & $\begin{array}{c}\text { Growth } \\
\mathbf{( \% )}\end{array}$ & $\begin{array}{c}\text { Length } \\
(\mathbf{c m})\end{array}$ & $\begin{array}{c}\text { Fresh weight } \\
\mathbf{( g )}\end{array}$ & $\begin{array}{c}\text { Dry weight } \\
\mathbf{( m g )}\end{array}$ & $\begin{array}{c}\text { Rooting } \\
\mathbf{( \% )}\end{array}$ & $\begin{array}{c}\text { Fresh weight } \\
(\mathbf{m g})\end{array}$ & $\begin{array}{c}\text { Dry weight } \\
(\mathbf{m g})\end{array}$ \\
\hline $\mathbf{0}$ & $100.0 \mathrm{a}$ & $8.2 \mathrm{a}$ & $1.80 \mathrm{a}$ & $186 \mathrm{a}$ & $93.2 \mathrm{a}$ & $216 \mathrm{a}$ & $24.0 \mathrm{a}$ \\
$\mathbf{2 5}$ & $66.2 \mathrm{~b}$ & $4.8 \mathrm{~b}$ & $1.24 \mathrm{~b}$ & $140 \mathrm{~b}$ & $72.8 \mathrm{~b}$ & $152 \mathrm{~b}$ & $10.6 \mathrm{~b}$ \\
$\mathbf{5 0}$ & $59.8 \mathrm{~b}$ & $3.0 \mathrm{c}$ & $1.26 \mathrm{~b}$ & $130 \mathrm{~b}$ & $72.8 \mathrm{~b}$ & $84 \mathrm{c}$ & $7.4 \mathrm{c}$ \\
$\mathbf{7 5}$ & $59.6 \mathrm{~b}$ & $2.2 \mathrm{~d}$ & $1.02 \mathrm{~b}$ & $88 \mathrm{c}$ & $59.8 \mathrm{~b}$ & $58 \mathrm{c}$ & $4.6 \mathrm{~d}$ \\
$\mathbf{1 0 0}$ & $43.2 \mathrm{c}$ & $1.6 \mathrm{~d}$ & $0.96 \mathrm{c}$ & $82 \mathrm{c}$ & $43.2 \mathrm{c}$ & $52 \mathrm{c}$ & $1.6 \mathrm{~d}$ \\
\hline
\end{tabular}

Means in the same column followed by the same letter(s) are not significantly different according to Dancan's multiple range test $(\mathrm{P} \leq \mathbf{0 . 0 5})$.

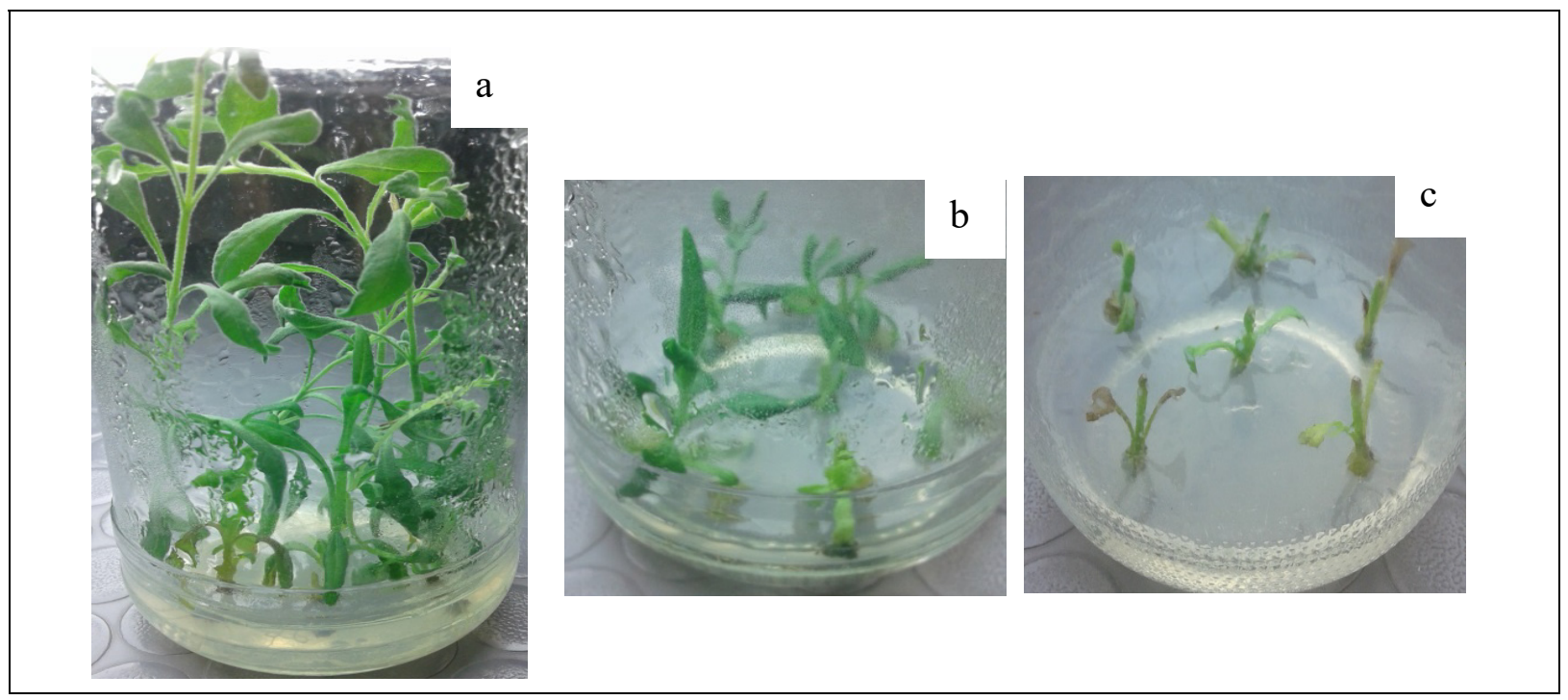

Fig. 1. Salvia officinalis single node explants grown on medium enriched with 0,100 and $125 \mathrm{mM} \mathrm{NaCl}$ (a, b and c, respectively).

and DW were more pronounced than that of shoots (Table, 1). At 25 and $50 \mathrm{mM} \mathrm{NaCl}$ the percentage of explants which developed roots were higher than that of which showed shoot growth. Results showed that $100 \mathrm{mM}$ $\mathrm{NaCl}$ reduced the ability of explants to develop new growth and rooting of $S$. officinalis explants to $43 \%$. Additionally, plantlet growth in terms of shoot and root FW and DW were significantly reduced for more than $50 \%$. But, it should be noticed that all traits except rooting percentage did not varied $(p \leq 0.5)$ between 75 and $100 \mathrm{mM}$ of $\mathrm{NaCl}$ treatments. Therefore, $100 \mathrm{mM} \mathrm{NaCl}$ was considered as a selective agent for the next experiments.
Reducing survivability of $S$. officinalis explants due to high salt stress $(125 \mathrm{mM}$ $\mathrm{NaCl}$ ) and inhibition the percentage of explants which showed growth under 75 and $100 \mathrm{mM}$ were observed on this investigation. The reduction on root fresh and dry weight under salt stress is a known phenomenon under salt stress. Reduction of plant growth and dry matter accumulation under salt stress conditions has been reported in several medicinal plants (Mohamed et al., 2000 and Muhammad and Hussain, 2010). Glenn et al. (1999) stated that excessive salt above what plants tolerate limits plant growth and productivity and could lead to plant death. Siler et al. (2007) demonstrated that roots are 
the first organs affected and most sensitive ones by salt stress. This retardation could be attributed to the inhibition of cell elongation (Bandeoglu et al., 2004)

\section{In vitro selection $\mathrm{NaCl}-$ tolerant clone:}

All leaf explants as well as 4-month old shoot clumps cultured on RM enriched with $100 \mathrm{mM} \mathrm{NaCl}$ showed necrosis during the $1^{\text {st }}$ culture. Thereafter, these cultures get brown and died after subculturing. On contrast to that, shoot clumps which originally cultured on RM for 12 weeks showed different levels of necrosis (Fig., 2). Nevertheless, green survived clumps were recovered after the $3^{\text {rd }}$ subcultures. The recovered shoot clumps were subcultured onto SGM where 4 shoots were elongated. These shoots were individually elongated on free- $\mathrm{NaCl}$ medium and called clone 1, 2, 3 and 4 . The elongated shoots were individually cloned by single node explants on free-NaCl SGM. Following the theoretical base of somaclonal variations in vitro culture techniques was applied to produce variants which were more resistant to different environmental abiotic stress assuming that there is a parallel between cellular and in vivo plant responses (Mohamed et al., 2000; Rai et al., 2011; Krishna et al., 2016; Rao and Sandhya, 2019). These investigators showed similar responses to our study of different plant species to in vitro stress agent such as $\mathrm{NaCl}$, mannitol and PEG.

\section{Evaluation of the selected clones for $\mathrm{NaCl}$ stress:}

\section{Explant growth:}

The number of control explants of $S$. officinalis that showed new growth on stressed medium was reduced $(\mathrm{p} \leq 0.5)$ to $60 \%$ nevertheless, this reduction was similar to all clones. The percentage of selected clone-explants which showed further shoot growth on $\mathrm{NaCl}$ enriched medium was ranged from 50 to $72 \%$. Salt enriched medium clearly reduced shoot lengths of the selected clone (Fig., 2). The control plantlets and clone 1 cultured on free- $\mathrm{NaCl}$ medium had the highest shoot length (10.7 and 11.3 $\mathrm{cm}$. respectively; $\mathrm{p} \geq 0.5$ ) which reduced to 1.3 and $3.6 \mathrm{~cm}$ respectively, under stress conditions (Table, 2). Under this condition clone 1 and 3 had higher shoot length than the control and other clones. Overall, the minimum reduction $(63 \%)$ on shoot $\mathrm{FW}$ due to salt stress was for clone 3 however, the maximum reduction $(88 \%)$ was for control plant.

Control plantlet grown on free- $\mathrm{NaCl}$ medium had the highest shoot FW (330 mg) whereas, this value was significantly reduced to $208,196,141$, and $135 \mathrm{mg} /$ plantlet for the four selected clones, respectively (Table, 2). Overall, clone had the highest shoot FW $(159 \mathrm{mg} /$ plantlet) whereas control plantlets grown on stress conditions had significantly the lowest shoot FW (90 mg/plantlet). Stress condition significantly reduced the FW for control and clone 2 however, the FW of the other clones did not reduce due to $\mathrm{NaCl}$. Moreover, these plantlets had significantly lower shoot DW under stress conditions. Shoot DW were significantly affected with and varied among the clones. Under nonstress conditions all clones had shoot DW lower than that of the control treatment however, the variance among the clones on this condition was not significant (Table, 2).

All explants developed roots on $\mathrm{NaCl}-$ free medium while on $\mathrm{NaCl}$-enriched medium the percentage of explants which developed roots were significantly reduced to $60-72 \%$ with no significant difference among them. However, for all tested plants $\mathrm{NaCl}$ significantly reduced the percentage of rooting. Clone 1 had significantly the highest root FW (92.7 mg/plant) whereas the control plant had $65.3 \mathrm{mg} /$ plantlets. Salt stress significantly reduced the root $\mathrm{FW}$ of control and clone 2 and 4 plantlets (Table, 2). The reduction on root $\mathrm{FW}$ of these plantlets compared with these on $\mathrm{NaCl}$-free medium were 75, 48 and $84 \%$ respectively. Root DW did not represent as it was difficult to measure it for many plantlets. The effect of $\mathrm{NaCl}$ on growth of $S$. officinalis nodalexplant was discussed above. Whereas, the variation among in vitro regenerated plantlets 


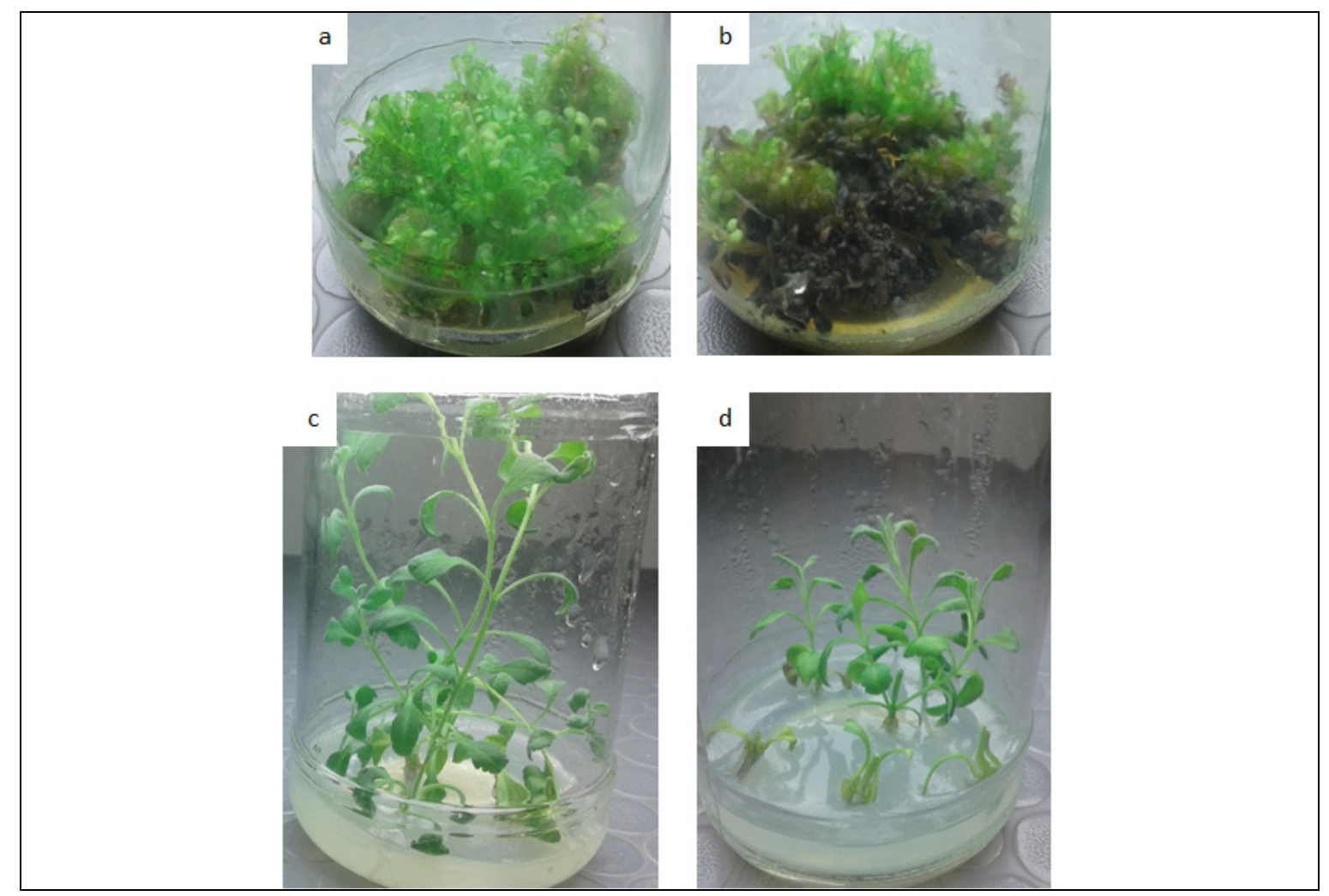

Fig. 2. Salvia officinalis shoot clumps grown on MS medium with $1.5 \mathrm{ml}$ TDZ and 1 mg/l IAA (a), shoot clumps grown on same medium included $100 \mathrm{mM} \mathrm{NaCl}$ (b), single node explants of clone 1 grown on free-NaCl medium (c) and on medium with $100 \mathrm{mM}$ NaCl.

Table 2. Effect of $\mathrm{NaCl}$ on growth of Salvia officinalis single node explants excised form in vitro $\mathrm{NaCl}$-tolerant selected clone.

\begin{tabular}{|c|c|c|c|c|c|c|c|c|}
\hline \multicolumn{2}{|c|}{ Treatment } & \multicolumn{4}{|c|}{ Shoot } & \multirow[b]{2}{*}{$\begin{array}{l}\text { Chlorophyll } \\
\text { (SPAD) }\end{array}$} & \multicolumn{2}{|c|}{ Root } \\
\hline Explant & $\begin{array}{l}\mathrm{NaCl} \\
(\mathrm{mM})\end{array}$ & $\begin{array}{c}\text { Growth } \\
(\%)\end{array}$ & $\begin{array}{l}\text { Length } \\
\text { (cm) }\end{array}$ & $\begin{array}{c}\text { Fresh } \\
\text { weight } \\
\text { (mg) }\end{array}$ & $\begin{array}{c}\text { Dry } \\
\text { weight } \\
\text { (mg) }\end{array}$ & & Rooting (\%) & $\begin{array}{c}\text { Fresh weight } \\
\text { (mg) }\end{array}$ \\
\hline \multirow{2}{*}{ Control } & $\mathbf{0}$ & $100 \mathrm{a}$ & $10.7 \mathrm{a}$ & $330 \mathrm{a}$ & $32.3 \mathrm{a}$ & $45.2 \mathrm{a}$ & $100.0 \mathrm{a}$ & $65.3 \mathrm{a}$ \\
\hline & 100 & $60 c$ & $1.3 \mathrm{e}$ & $90 \mathrm{e}$ & $6.7 \mathrm{e}$ & $30.8 b-d$ & $60.7 \mathrm{c}$ & $16.0 \mathrm{cde}$ \\
\hline \multirow{2}{*}{ Clone 1} & 0 & $89 b$ & $11.3 \mathrm{a}$ & $208 b$ & $23.0 \mathrm{bc}$ & $36.1 \mathrm{~b}$ & $88.7 \mathrm{ab}$ & $92.7 b c$ \\
\hline & 100 & $72 \mathrm{c}$ & $3.6 \mathrm{~d}$ & $159 b-d$ & $15.7 \mathrm{~cd}$ & $24.3 d$ & $61.0 \mathrm{c}$ & $48.3 b$ \\
\hline \multirow{2}{*}{ Clone 2} & $\mathbf{0}$ & $100 \mathrm{a}$ & $8.4 b$ & $196 b c$ & $25.7 \mathrm{ab}$ & $25.8 \mathrm{~cd}$ & $100 \mathrm{a}$ & $60.3 \mathrm{a}$ \\
\hline & 100 & $72 c$ & $2.2 \mathrm{de}$ & $116 d$ & $9.3 d$ & $33.1 \mathrm{bc}$ & $60.0 \mathrm{c}$ & $31.0 \mathrm{bc}$ \\
\hline \multirow{2}{*}{ Clone 3} & $\mathbf{0}$ & $100 \mathrm{a}$ & $9.3 b$ & $141 b-d$ & $16.3 b-d$ & $38.8 \mathrm{ab}$ & $100 \mathrm{a}$ & $26.3 b-d$ \\
\hline & 100 & $66 \mathrm{c}$ & $3.4 \mathrm{~d}$ & $117 d$ & $17.0 \mathrm{~b}-\mathrm{d}$ & $22.3 b c$ & $72 b c$ & $14.0 \mathrm{de}$ \\
\hline \multirow{2}{*}{ Clone 4} & $\mathbf{0}$ & $83 c$ & $6.4 \mathrm{c}$ & $135 \mathrm{~cd}$ & $17.0 b-d$ & $36.3 b$ & $100 \mathrm{a}$ & $68.7 \mathrm{a}$ \\
\hline & 100 & $50 \mathrm{c}$ & $1.5 \mathrm{e}$ & $103 d$ & $7.2 \mathrm{~d}$ & $23.8 \mathrm{~d}$ & $66 b c$ & $11.2 \mathrm{e}$ \\
\hline
\end{tabular}

Means in the same column followed by the same letter(s) are not significantly different according to Dancan's multiple range test $(P \leq 0.05)$. 
under stress condition which can be due to somaclonal variation was discussed above.

\section{Chlorophyll content:}

The chlorophyll content measured as SPAD unit was significantly varied among tested plantlets, as well as, the concentration of $\mathrm{NaCl}$. Moreover, there was a significant interaction among the type of plantlets and $\mathrm{NaCl}$ concentrations (Table, 2). Under nonstress conditions the analysis of variance for SPAD measurements showed differences $(\mathrm{p} \leq 0.5)$ among the control plantlets (45.2) and the selected clones except clone 3 which had (38.8). Under stress conditions the lowest SPAD value (23.8) was being for clone 4 plantlets whereas, the highest value being for these of clone 3 . Only, clone 2 had higher SPAD under stress conditions than non-stress ones (25.8 and 33.1, respectively). Our results regarding the reduction of chlorophyll content due to $\mathrm{NaCl}$ stress is in agreement with previous results of Taibi et al. (2016) and Turan et al. (2007). The decrease in chlorophyll content in saltstressed plants has been considered as a classic symptom of oxidative stress which inhibits its biosynthesis, together with the activation of its degradation by the enzyme chlorophyllase (Santos, 2004).

\section{Proline content:}

Proline content (Table, 3) was affected by $\mathrm{NaCl}$ and varied $(\mathrm{p} \leq 0.05)$ among clones and the control plants. Control and clone 1 plantlets and had significantly the lowest proline content (4.48 and $5.05 \mu \mathrm{g} / \mathrm{g} \mathrm{FW}$, respectively) with no significant difference between them. Under stress conditions clone 2 had overall, the highest proline content (29.26 $\mu \mathrm{g} / \mathrm{g} \mathrm{FW})$ however, clone 1 had the lowest content $(9.43 \mu \mathrm{g} / \mathrm{g} \mathrm{FW})$ which was similar to that of control plantlets $(8.42 \mu \mathrm{g} / \mathrm{g}$ FW). The highest increment (about 3.5-fold) of proline due to $\mathrm{NaCl}$ stress was assessed for clone 2. The positive correlation between plant salt tolerance and proline accumulation has been provide in different plant species (Xue et al., 2009 and Shahbaz et al., 2011, Brenes etal., 2020). Proline could be directly involved in the mechanisms of salt tolerance, so that higher contents mean higher tolerance (Al Hassan et al., 2016). Our results showed a significant variation among the selected clone in proline content which confirmed with in vitro results obtained by Mohamed et al. (2000) and Androw et al. (2005) due to somaclonal variations. They stated that selected clones of different plant species with high proline content could withstand in vivo abiotic stress.

\section{Total soluble sugars content:}

The analysis of variance showed TSS was significantly varied among tested plants and due to salt stress moreover, there were a significant interaction between the plant types and $\mathrm{NaCl}$ treatment. The control plantlets grown on salt-stress and nonstressed medium had 35.26 and $36.92 \mathrm{mg} / \mathrm{g}$ $\mathrm{FW}$, respectively; $(\mathrm{p} \leq 0.05)$. On the nonstressed medium plantlets of clone 1 and 3 had significantly the highest concentration (38.33 and $37.74 \mathrm{mg} / \mathrm{g} \mathrm{FW}$, respectively). This value significantly reduced to 36.71 $\mathrm{mg} / \mathrm{g} \mathrm{FW}$. Although TSS play a vital role in osmoregulation under stress conditions in some plant species for clone 1 however, the reduction under stress condition $36.78 \mathrm{mg} / \mathrm{g}$ FW for clone 3 was not significant. Therefore, these results could suggest that TSS contents do not associate with the degree of salt tolerance, and probably do not play any significant role in the responses to salt stress of $S$. officinalis. Gil et al. (2013) referred that TSS play a vital role in osmoregulation under stress conditions however this depending on plant species. Recently, Brenes et al. (2020) had similar results however these results were in contrast with Mohamed et al. (2000).

\section{Total soluble protein content:}

Total soluble proteins of $S$. officinalis plants were significantly varied among the selected clones and the control plants which had $26.1 \mathrm{mg} / \mathrm{g} \mathrm{FW}$ on NaCl-free medium. There was no significant increment on TSP 
M.A.H. Mohamed et al.

Table 3. Effect of $\mathrm{NaCl}$ on proline and total soluble sugars and protein content as well as the activity of CAT, APX and POX of Salvia officinalis plantlets.

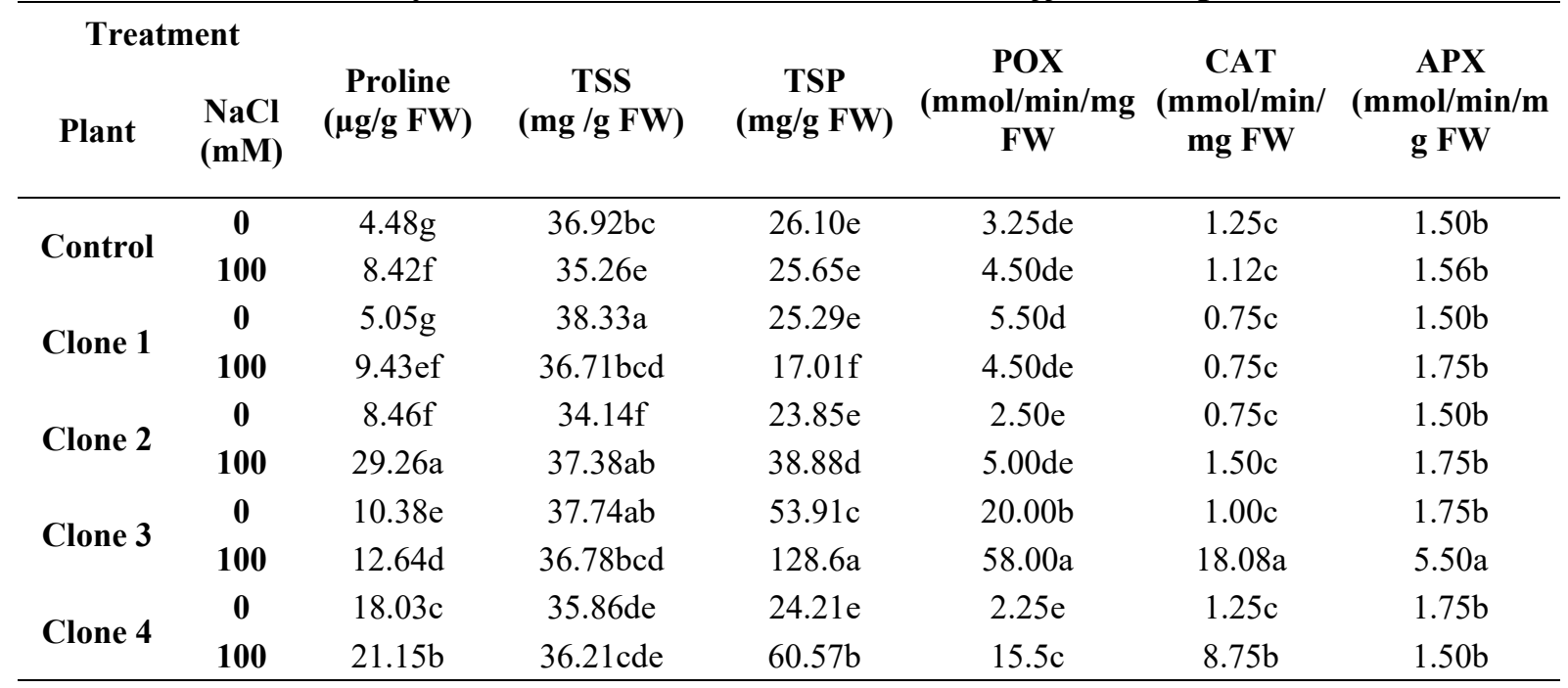

Means in the same column followed by the same letter(s) are not significantly different according to Dancan's multiple range test $(P \leq 0.05)$.

for control plantlets due to salt stress however, all other clones had significantly higher TSP under salt stress. The content of TSP for clone 1 which was the lowest value $(17.0 \mathrm{mg} / \mathrm{g} \mathrm{FW})$ was significantly decreased under salt stress compared with non-stress condition (Table, 3). However, all other clones had significantly higher TSP under stress conditions. Clone 3 and 4 plantlets which grow on $\mathrm{NaCl}$-enriched medium had more than 2-fold of TSP than that of plantlets on non-stressed medium. Overall, under stress conditions clone 3 had significantly the highest TSP $(128.1 \mathrm{mg} / \mathrm{g}$ FW) which is about 5-fold than that of control plants on non-stressed medium and about 2.5-fold than that assessed on the same clone under non stress condition. The obtained results are in agreement with those obtained by Ayala-Astorga and AlcarazMeléndez (2010). To survive under stress, plants accumulate organic solutes included proteins that protect cells from stress damage. Timasheff and Arakawa (1989) presumed that the accumulation of organic solutes under salt stress was involved in some protection mechanisms such as the restoration of turgor and cell volume, the decrease exogenous nitrate of the cell damage prompted by free radicals, the protection of enzymes and membrane structures.

\section{Antioxidant enzymes activity}

Significant differences were found among the selected clones and control plants in terms of CAT, POX, and APX activity (Table, 3). The highest activities of these enzymes (58.00, 18.08, and 5.50 $\mu \mathrm{mol} / \mathrm{min} / \mathrm{mg} \mathrm{FW}$ ) occurred in clone 3 under stress condition. Whereas, the activities of these enzymes on the control plants which grow in $\mathrm{NaCl}$-free medium were $3.25,1.25$, and $1.5 \mu \mathrm{mol} / \mathrm{min} / \mathrm{mg} \mathrm{FW}$ respectively. On $\mathrm{NaCl}$-enriched medium plantlets of clone 3 and 4 had higher $(p \leq 0.5)$ activity of CAT than the control plantlets. Whereas, there was a higher significant activity on APX which grow on salt-stressed medium. The highest increase of CAT due to salt stress was assessed for clone 3 where it increased from 20.0 to $58.0 \mu \mathrm{mol} / \mathrm{min} / \mathrm{mg} \quad \mathrm{FW}$. Compared with the control plant grown on non-stressed medium $(1.25 \mu \mathrm{mol} / \mathrm{min} / \mathrm{mg}$ FW) the activity of POX. Only plantlets of clone 3 and 4 had higher activity of POX (18.08 and $8.75 \mu \mathrm{mol} / \mathrm{min} / \mathrm{mg} \mathrm{FW}$ ) under stress condition compared with other 
treatments. However, there was a significant difference between these values.

Our results regarding the antioxidant enzymes activity of some was similar to these obtained by Çelik, and Atak (2012) and extensively revived by Joseph and Jini (2010) and in plant some enzymatic processes contribute in the detoxification of ROS which could cause oxidative injury to many cellular components such as membrane lipids, proteins and nucleic acids (Guo et al., 2019). Several anti-oxidant molecules/enzymes are involved in this detoxification of ROS in plants. In our study, a significant varietal dissimilarity had been found regarding the antioxidant enzyme activities of selected clone. The enzyme activities (CAT, APX and POX) were found constitutively higher in some clone under salt-tolerant as compared to the non-stressed conditions (de Castro et al., 2020).

Obtained results from this study were in concurrence with the previous obtained results of many studies showed a using somaclonal variation as an efficient tool for in vitro selection a stress-tolerant clones of many plant species. A negative correlation between increased salt stress and plant growth was well documented. However, there were positive correlation between accumulation of some organic molecules such as proline and TSP as well as antioxidant activity of some ezymes and salt tolerance. From this it is possible to concluded that in vitro culture of $S$. officinalis can be easily used in screening and selecting for the salt tolerance plant with other physiological criteria.

\section{REFERENCES}

Al Hassan, M.; López-Gresa, M.P.; Boscaiu, M. and Vicente, O. (2016). Stress tolerance mechanisms in juncus responses to salinity and drought in three juncus species adapted to different natural environments. Plant Biol., 43:949-960.

Al-Amier, H. and Craker, L.E. (2007). Invitro selection for stress tolerant spearmint. In: Janick, J. and Whipkey, A. (eds.), Issues in New Crops and New Uses, ASHS Press, Alexandria, VA. USA, pp. 306-310.

Alhasnawi, A.N. (2019). Role of proline in plant stress tolerance: A mini review Research on Crops, 20:223-229.

Andrew, J.W. and Bennett, I.J. (2005). The effect of salt stress and abscisic acid on proline production, chlorophyll content and growth of in vitro propagated shoots of Eucalyptus camaldulensis. Plant Cell, Tissue and Organ Cult., 82:189-200

Asada, K. (1992). Ascorbate peroxidase a hydrogen peroxide scavenging enzyme in plants. Physiol Plant, 85: 235.

Ayala-Astorga, G.I. and Alcaraz-Meléndez, L. (2010). Salinity effects on protein content, lipid peroxidation, pigments, and proline in Paulownia imperialis (Siebold \& Zuccarini) and Paulownia fortunei (Seemann \& Hemsley) grown in vitro. E. J. of Biotechnol., 13:13-24.

Bandeoglu, E.F.; Eyidogan, M. and Oktem, H.A. (2004). Antioxidant Responses of shoots and roots of lentil to NaCl-salinity stress. Plant Growth Regul., 42: 69-7

Baricevic, D. and Bartol, T. (2000). The biological/pharmacological activity of the salvia genus. In: Kentisoz, S.E. (ed.), Sage, The Genus Salvia, Overseas Publishers Association, N.V., The Netherlands, pp.143-223.

Bates, L.S.; Waldern, R.P. and Teare, I.D. (1973). Rapid determination of free proline from water stress studies, Plant Soil, 39: 205-207.

Bisht, S.S.; Bisht, A.S. and Singh, R. (2017). In-vitro mutagenesis induction to improve abiotic stress in tissue cultured plantlet of Picrohiza kurroa Royle ex. Benth: An endangered plant of Western Himalayas, India. Med. Aromat. Plants (Los Angel), 6:1-11. https://doi.org/10.4172/21670412.1000287 
Brenes, M.; Solana, A.; Boscaiu, M.; Fita, A.; Vicente, O.; Calatayud, A.; Prohens, J. and Plazas, M. (2020). Physiological and biochemical responses to salt stress in cultivated eggplant (Solanum melongena L.) and in S. insanum L., a close wild relative. Agronomy, 10:651670.

Çelik, Ö. and Atak, Ç. (2012). The effect of salt stress on antioxidative enzymes and proline content of two Turkish tobacco varieties. Turk. J. Biol., 36:339-356.

De Castro, K.M.; Batista, D.S. and Silva, T.D. (2020). Water deficit modulates growth, morphology, and the essential oil profile in Lippia alba L. (Verbenaceae) grown in vitro. Plant Cell Tiss. Organ Cult., 141:55-65.

Dweck, A.C. (2000). The folklore and cosmetic use of various salvia species. In: kintzios, S.E. (ed.), Sage, the genus salvia, Overseas Publishers Association, N.V., The Netherlands, pp. 1-26.

Farooq, M.; Wahid, A.; Ito, O.; Lee, D.J and Siddique, K.H.M. (2009). Advances in drought resistance of rice. Crit. Rev. Plant Sci., 28:199-217.

Ghaher, M.; Kahrizi, D. and Bahrami, G. (2017). Effect of mannitol on some morphological characteristics of in vitro Stevia rebaudiana Bertoni Matin. Biharean Biologist, 11: 94-97.

Gil, R.; Boscaiu, M.T.; Lull, C.; Bautista, I.; Lidón, A. and Vicente, O. (2013). Are soluble carbohydrates ecologically relevant for salt tolerance in halophytes?. Plant Biol., 40: 805-818.

Glenn, E.P.; Brown, J.J. and Blumwald, E. (1999). Salt tolerance and crop potential of halophytes. Critical Review in Plant Sciences, 18:227-255.

Guo, Q.; Liu, L., and Barkla, B.J. (2019). Membrane lipid remodeling in response to salinity. Int. J. Mol. Sci., 20:4264.

Gupta, B. and Huang, B. (2014). Mechanism of salinity tolerance in plants: physiological, biochemical, and molecular characterization. Inter. J. of Genomics, http://dx.doi.org/10.1155/2014/701596

Havir, E.A. and Mellate, N.A. (1987). Biochemical and developmental characterization of multiple forms of catalase in tobacco leaves. Plant Physiol., 84: 450- 455.

Jermyn, M.A. (1975). Increasing the sensitivity of the anthron method for carbohydrate. Anal. Biochem., 68:332335.

Jolayemi, O.L.; Opabode, J.T. and Badara, G. (2018). In vitro response of three contrasting cassava (Manihot esculenta Crantz) varieties to mannitol-induced drought stress. Agricult. Tropica Et Subtropica, 51:125-131.

Joseph, B. and Jini, D. (2010). Insight into the role of antioxidant enzymes for salt tolerance in plants. International Journal of Botany, 6:456-464.

Keunen; P.D.; Vangronsveld, J.; Van Den, W.E. and Cuypers, A. (2013). Plant sugars are crucial players in the oxidative challenge during abiotic stress: extending the traditional concept. Plant, Cell and Environment, 36:1242-1255.

Klapheck, S.; Zimmer, I. and Cosse, H. (1990). Scavenging of hydrogen peroxide in endosperm of Ricinus communis by ascorbate peroxidase. Plant Cell Pysiol., 31: 1005- 1013.

Krishna, H.; Alizadeh, M.; Singh, D.; Singh, U.; Chauhan, N.; Eftekhari, M. and Sadh, R.K. (2016). Somaclonal variations and their applications in horticultural crops improvement. Biotech, 6:1-18.

Larkin, P.J. and Scowcroft, W.R. (1981). Somaclonal variation a novel source of variability from cell cultures for plant improvement. Theor. Appl. Genet., 60:197-214.

Lowry, O.H; Rosebrough, N.J.; Farr, A.L and Randall, R.J. (1951). Protein 
measurement with the folin phenol reagent. J. Biol. Chem., 193: 265-75.

Maehly, A.C. and Chance, B. (1954). The assay of catalase and peroxidase. In: Glick, D. (ed.), Methods of Biochemical Analysis, Volume 1, Interscience Publishers, Inc., pp. 357-424.

Mohamed, M.A.H.: Aly, M.K.; Ahmed, E.T. and Abd El-Latif, S.A.H. (2019). Effect of plant growth regulators on organogenesis of Salvia officinalis L. plants. Minia J. of Agric. Res. \& Develop., 39: 401-414.

Muhammad, Z. and Hussain, F. (2010). Vegetative growth performance of five medicinal plants under $\mathrm{NaCl}$ salt stress. Pak. J. of Botany, 42:303-316

Mukherjee, S.P. and Choudhuri, M.A. (1983). Implications of water stressinduced changes in the levels of endogenous ascorbic acid and hydrogen peroxide in Vigna seedlings. Plant Physiol., 58:166- 170.

Murashige, T. and Skoog, F. (1962). A revised medium for rapid growth and bioassays with tobacco tissue cultures. Physiologa Plantarum, 15:473-497.

Parvaiz, A. and Satyawati, S. (2008). Salt stress and phyto-biochemical responses of plants - a review. Plant Soil Environ., 54: 89-99.

Patricia, M.L.; López, María, C.; Jürgen, De M.; Celia, B. and María, A.A. (2013). In vitro establishment of Salvia hispanica L. plants and callus. Biotecnología Vegetal, 13:203-207.

Rai, M.K.; Kalia, R.K.; Singh, R.; Gangola, M.P. and Dhawan, A.K. (2011). Developing stress tolerant plants through in vitro selection - an overview of the recent progress. Environ. Exp. Bot., 71:89-98.

Rao, S. and Sandhya, H. (2019). In vitro selection and genetic engineering for abiotic stress tolerant plants and underlying mechanism. In: Ramakrishna,
A. and Gill, S.S. (eds.), Metabolic Adaptations in Plants During Abiotic Stress, CRC Press, Taylor \& Francis Group, UK, pp. 283-290.

Sairam, R.K. and Tyagi, A. (2004). Physiological and molecular biology of salinity stress tolerance in plants. Current Sci., 86: 407-420.

Santos, C.V. (2004). Regulation of chlorophyll biosynthesis and degradation by salt stress in sunflower leaves. Scientia Horticult., 103:93-99.

Shahbaz, M.; Ashraf, M.; Akram, N.A.; Hanif, A.; Hameed, S.; Joham, S. and Rehman, R. (2011). Salt induced modulation in growth, photosynthetic capacity, proline content and ion accumulation in sunflower (Helianthus annuus L.). Acta Physiologiae Plantarum, 33:1113-1122.

Siler, B.; Misic, D.; Filipovic, B.; Popovic, Z.; Cvetic, T. and Mijovic, A. (2007). Effect of salinity stress on growth and photosynthesis of common centaury (Centaurium erythraea). Arch. Biol. Sci. Belgrade, 59:129-134.

Singh, D., Kaur, S. and Kumar, A. (2020). In vitro drought tolerance in selected elite clones of Eucalyptus tereticornis Sm. Acta Physiol Plant, 42:17.

Taïbi, K.; Taïbi, F.; Abderrahim, L.A.; Ennajah, A.; Belkhodja, M. and Mulet, J.M. (2016). Effect of salt stress on growth, chlorophyll content, lipid peroxidation and antioxidant defense systems in Phaseolus vulgaris L. South African Journal of Botany, 105:306-312.

Timasheff, S.N and Arakawa, T. (1989). Stabilization of protein structure by solvents. In: Creighton TE (ed.), Protein Structure: A Practical Approach, Oxford: IRL Press, pp. 331-44.

Turan, M.A.; Turkmer, N. and Taban, N. (2007). Effect of $\mathrm{NaCl}$ on stomatal resistance and proline chlorophyll, $\mathrm{NaCl}$ and $\mathrm{K}$ concentrations of lentil plants. Journal of Agronomy, 6:378-381. 


\section{M.A.H. Mohamed et al.}

Uddling, J.; Gelang-Alfredsson, J.; Piikki, K. and Pleijel, H. (2007). Evaluating the relationship between leaf chlorophyll concentration and SPAD-502 chlorophyll meter readings. Photosynth Res., 91:3746.

Xue, X.; Liu, A. and Hua, X. (2009). Proline accumulation and transcriptional regulation of proline biothesynthesis and degradation in Brassica napus. BMB Reports, 42: 28-34.

Yamaguchi-Shinozaki, K. and Shinozaki, K. (2006). Transcriptional regulatory networks in cellular responses and tolerance to dehydration and cold stresses. Annu. Rev. Plant. Biol., 57:781803.

\section{الاتتخاب المعملي وصفات السلالات المنتخبة لنباتات المريمية}

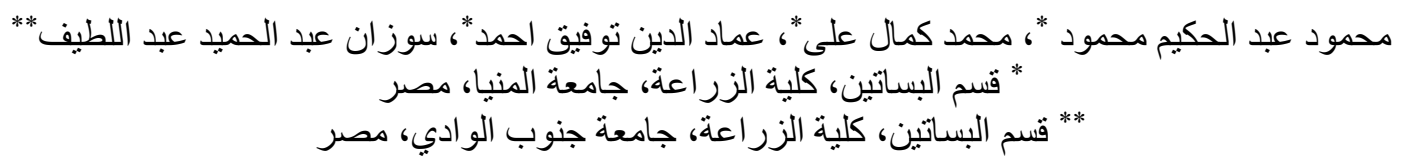

تعد نباتات المريمية من النباتات الجذابة واسعة الانتشار في العديد من دساتير الادوية العالمية. تم الحصول على العي كتل

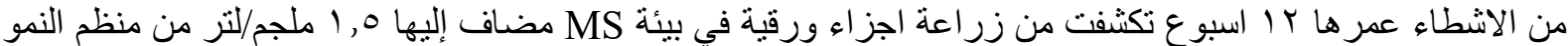

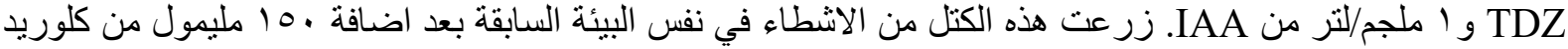

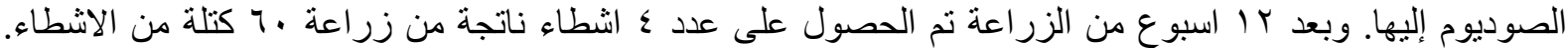

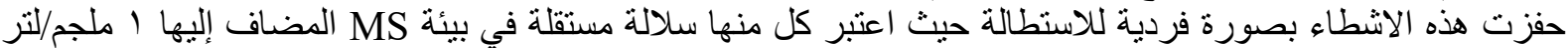

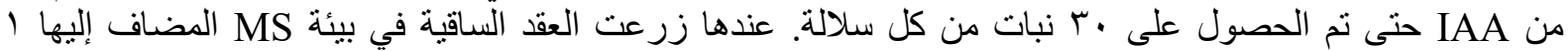

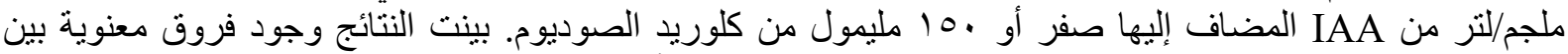

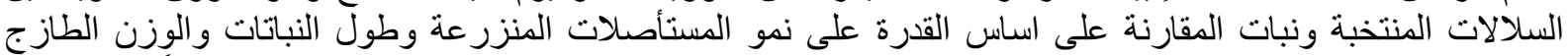

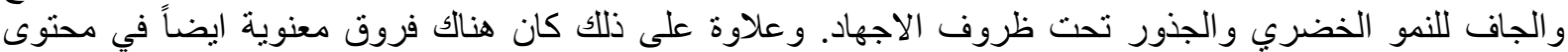

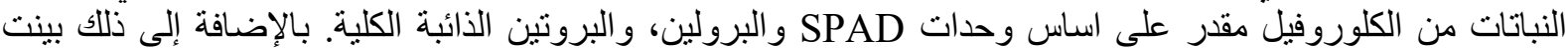

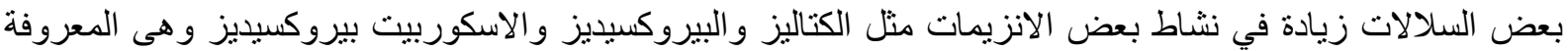

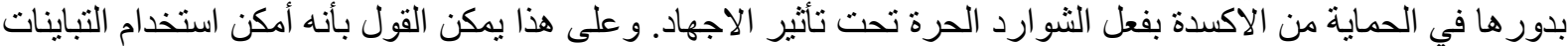

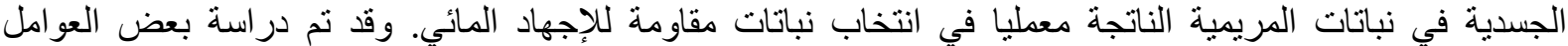
الفسيولوجية الحاسمة في مقاومة النباتات لإجهاد الملوحة. 